\title{
Predicting Water Quality Changes from Artificial Recharge Sources to Nearby Wellfields
}

\author{
J. E. Moran, M. L. Davisson, G. B. Hudson, \\ C. Koester, J. Beiriger
}

January 23, 1998

This is an informal report intended primarily for internal or limited external distribution. The opinions and conclusions stated are those of the author and may or may not be those of the Laboratory.

Work performed under the auspices of the U.S. Department of Energy by the Lawrence Livermore National Laboratory under Contract W-7405-Eng-48. 


\section{DISCLAIMER}

This document was prepared as an account of work sponsored by an agency of the United States Government. Neither the United States Government nor the University of California nor any of their employees, makes any warranty, express or implied, or assumes any legal liability or responsibility for the accuracy, completeness, or usefulness of any information, apparatus, product, or process disclosed, or represents that its use would not infringe privately owned rights. Reference herein to any specific commercial product, process, or service by trade name, trademark, manufacturer, or otherwise, does not necessarily constitute or imply its endorsement, recommendation, or favoring by the United States Government or the University of California. The views and opinions of authors expressed herein do not necessarily state or reflect those of the United States Government or the University of California, and shall not be used for advertising or product endorsement purposes.

This report has been reproduced directly from the best available copy.

Available to DOE and DOE contractors from the Office of Scientific and Technical Information

P.O. Box 62, Oak Ridge, TN 37831

Prices available from (615) 576-8401, FTS 626-8401

Available to the public from the

National Technical Information Service

U.S. Department of Commerce

5285 Port Royal Rd.,

Springfield, VA 22161 


\section{Predicting Water Quality Changes from Artificial Recharge Sources to Nearby Wellfields}

97-ERD-139

J. E. Moran, M. L. Davisson, G. B. Hudson, C. Koester, and J. Beiriger

Isotope tracer technologies have proven to be powerful tools for addressing questions related to surface water-ground water interactions. The Alameda County Water District artificially recharges tens of thousands of acre- $\mathrm{ft}$ of water annually, delivered from Alameda Creek, in order to augment dwindling ground water supplies, and to maintain a barrier to seawater intrusion. We are using a suite of isotope tracers to track water movement, source characteristics and accompanying water quality changes from ACWD recharge facilities to nearby wells. The data gathered during the three year project will allow quantification of dilution by ambient basin ground water, subsurface travel times, and several key water quality parameters, including degree of degradation of organic compounds, the fate of trace metals during recharge and subsurface transport, and sources and transport of major ions (salts).

Reconnaissance work was carried out on naturally occurring isotopes in order to better understand the hydrogeology of the ground water basin. The basin is dissected by the Hayward Fault, and geologic conditions vary greatly on either side of the fault. Stable isotopes of oxygen, carbon (measured on the dissolved inorganic component), helium, and other noble gases, along with radiocarbon (measured on DIC) and tritium, were measured on water samples from production and monitoring wells. The goal of the reconnaissance work was to age date the water at various depths and distances from the recharge ponds, to examine the chemical evolution of the water with age, and to examine the water for source-related variations in isotope composition.

Ground water ages were calculated by the tritium-helium method for three production wells in the Peralta-Tyson wellfield (in the Above Hayward Fault sub-basin), and for a monitoring well positioned between the recharge facilities and production wells, screened at three discreet intervals. While the monitoring well samples at all depths showed an age of less than one year, the production wells downgradient have ages of $3.7,4.7$, and 8.8 years. Stable isotopes of oxygen and carbon showed very little variation with depth in the monitoring well $\left(\delta^{18} 0-6.3\right.$ to -6.4 per mil and $\delta^{13} \mathrm{C}-14.3$ to -15.0 per mil), and suggest the presence of a slug of recently recharged, homogeneous water. The relatively old ages for the production wells suggest a water flow velocity of approximately $300 \mathrm{ft} / \mathrm{yr}$ for the short distance between the recharge ponds and the wells $(1500 \mathrm{ft})$, and indicate mixing between recently recharged water and ambient basin ground water. The heterogeneity evident in the water ages is also reflected in the $\delta^{18} \mathrm{O}$ and $\delta^{13} \mathrm{C}$ values, which range from -5.7 to -6.2 per mil and -14.5 to -15.7 per mil, respectively. ${ }^{14} \mathrm{C}$ levels of less than 100 percent modern corroborate that there is some mixing with older water.

The Below Hayward Fault sub-basin is layered alluvium with three major aquifers separated by extensive aquitards. The production wells (Mowry wellfield) draw from the nearsurface Newark aquifer (Mowry 1 and 7), the Centerville-Freemont aquifer (Mowry 3), and the deep (unnamed) aquifer (Mowry 2). Tritium helium ages are 3.0, 5.5, 19.7, and $30.8 \mathrm{yr}$., respectively, showing a familiar pattern of increasing water age with depth. The decay-corrected tritium level in the oldest water (from Mowry 2) is $450 \mathrm{pCi} /$, which is consistent with bomb fallout-influenced precipitation for 1966 . $\delta^{18} \mathrm{O}$ values show a strong correlation with ground water age and vary from -6.3 for Mowry 1 to -7.2 per mil for Mowry 2 . The trend toward more negative $\delta^{18} \mathrm{O}$ values may indicate increasing influence of water from a higher elevation source in the older, deeper waters. $\delta^{13} \mathrm{C}$ values show a correlation with ground water age as well, going from -17.1 in Mowry 1 to -13.4 in Mowry 2. Greater dissolution of carbonates (which have $\delta^{13} \mathrm{C}$ values of approximately 0 per mil) at depth may explain the less negative $\delta^{13} \mathrm{C}$ values. ${ }^{14} \mathrm{C}$ levels 
for the Mowry wellfield range from $99.6 \mathrm{pmC}$ for Mowry 7 to $84.2 \mathrm{pmC}$ for Mowry 2, consistent with the interpretation that there is an older, more evolved, ground water component at depth.

Because the solubility of the noble gases in water is temperature dependent, and the solubility curve is distinct for each gas, one can make a robust estimate of the temperature of recharge based on measurements of the dissolved abundances of $\mathrm{He}, \mathrm{Ne}, \mathrm{Ar}, \mathrm{Kr}$, and $\mathrm{Xe}$. For ACWD production wells, recharge temperatures are 14 to $15 \mathrm{C}$, with little variation between wells. The approximate equivalence of recharge temperatures with local soil temperatures means that recharge is slow enough for equilibrium to have been established between soil gas and recharging water. The similarity of recharge temperatures (near the mean annual temperature) likely sets a scale for dispersive mixing in the aquifer, so that water several years old is really a mixture of ages spanning at least one year.

Surface water from four locations in the ACWD watershed was analyzed for $\delta^{18} \mathrm{O}$ and several organic compounds, with the intent of finding an organic tracer for surface water/ground water interaction. Potential candidates for tracers of groundwater contamination that were found in sub-part per billion concentrations include simazine (an herbicide), oxidiazon (an herbicide often used on golf courses), and diazinon (an insecticide). In addition, a method was developed for determination of low-level methyl tert-butyl ether (MTBE - a gasoline additive), and shows promising results as a tracer for degradation of organic compounds during surface water/ground water interaction.

Several pieces of new information have been garnered from the reconnaissance work:

1. There is more source-related heterogeneity in water from the AHF sub-basin than has been assumed based on geologic cross-sections of the sub-basin.

2. Ground water ages from the Peralta-Tyson wellfield suggest the presence of a component of ambient basin ground water, and that travel times from recharge facilities to production wells are longer than previous analyses indicated.

3. There is a significant difference in the source characteristics of water sampled from the (AHF) monitoring well versus water sampled from (downgradient) production wells.

4. Relatively old water is present in the deeper aquifers in the BHF sub-basin.

5. Distinct flow paths and water sources are indicated for the three aquifers sampled by the Mowry wells.

The next phase of the project is to introduce artificial noble gas tracers into the recharge ponds, and monitor arrival times, dispersion, and dilution in wells. A different noble gas tracer will be used for each of two recharge ponds and Alameda Creek. Based on results from the first phase, several wells near to the recharge ponds were re-conditioned as monitoring wells. They will provide "initial conditions" for the tracer study. Many water quality parameters will be measured simultaneously, and changes will be tied in time with movement and dilution of the tracers. 


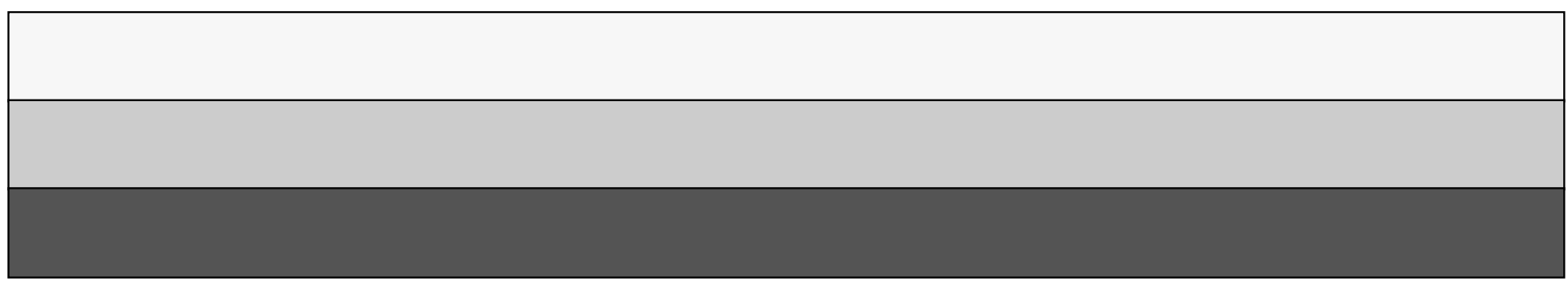

